ホタテ焼成微粒子付着バガスピスを混抄した機能紙の抗菌特性

\author{
小田 涼太 ${ }^{* 1, *} \cdot$ 木村 照夫*1 $・$ 稲垣 寛 ${ }^{* 2} \cdot$ 勝圓 進 ${ }^{* 3}$
}

\title{
Anti-bacterial Effect of High Performance Paper with Attached Scallop Particles to Bagasse Pith
}

\author{
Ryota Oda $^{* 1, *}$, Teruo Kimura ${ }^{* 1}$, Hiroshi Inagaki ${ }^{* 2}$, and Susumu Katsuen ${ }^{* 3}$ \\ ${ }^{* 1}$ Department of Advanced Fibro-Science, Kyoto Institute of Technology, \\ Goshokaido-cho, Matsugasaki, Sakyo-ku, Kyoto 606-8585, Japan \\ ${ }^{* 2}$ Kobe Women's University, 2-1 Higashisumaoayama, Suma-ku, Hyogo 654-8585, Japan \\ ${ }^{* 3}$ Kurabo Industries Ltd., 4-31, 2-Chome, Kyutaro-machi Chuo-ku, Osaka 541-8581, Japan
}

\begin{abstract}
A high performance antimicrobial paper was fabricated using composite of sugar cane bagasse pith and burned scallop particles with sugar cane bagasse pulp. The paper that was fabricated without degassing the composite pith had higher the scallop particle concentration on the top of surface displayed a greater value of anti-bacterial activity against methicillin-resistant Staphylococcus aureus than paper prepared that were mixed with degassing the composite pith and only mixed with scallop particle after 30minutes of cultivation. However the bagasse pulp and pith had antimicrobial activity as well as the scallop particle, the activity was not constant. The paper that was fabricated without degassing the composite pith had the stable activity and the quick effect.
\end{abstract}

(Received 23 December, 2013 ; Accepted 17 March, 2014)

\section{1. 緒 言}

抗菌加工製品は，特に日本において，清潔志向の高ま りから一般生活にも浸透しており, 台所用品, 風呂用品 さらには肌着や下着等多くの分野で使用されている[1]. また，一般生活以外においても，例えば病院における免 疫低下患者へのメチシリン耐性黄色ぶどう球菌(MRSA)に よる院内感染が問題となっており $[2-3]$, 抗菌加工製品の 需要は増々と増大している. 抗菌性物質として使用可能 なホ夕テ貝殼焼成粒子(以下, ホタテ粒子と称す)の水溶 液はMRSA に対しても抗菌性を示すことが知られている [4]. このホタテ粒子を用いて, 例えば通常のベッドシー ツに抗菌性を付与する場合に紛体あるいは溶液では扱い にくいが，紙状にすることでシーツの下に敷くことが可 能となり，簡便に抗菌性を付与できると考えられる。ま た, 既報[5]において, サトウキビの搾りかすから得られ るバガスピス (以下, ピスと称す)にホタテ粒子を物理的 に付着後, それを混抄し作製した機能紙は, ピスとパル プを単純に混抄，あるいはピスを用いずホ夕テ粒子のみ を混抄した場合に比べ，ホタテ粒子の歩留まりが向上す

\footnotetext{
\# corresponding author

*1 京都工芸繊維大学

*2 神戸女子大学

*3 倉敷紡績株式会社
}

ること, さらにはホタテ粒子付着後のピスに対する脱気 の有無で, ホ夕テ粒子の紙中での分布を変えることがで き, 紙の強度低下率を低減できることが明らかになって いる.このようなホタテ粒子を付着させたピスから構成 される機能紙は, 天然材料かつ未利用資源利用材料であ り, 人体のみならず地球環境にも配慮した抗菌紙である と言える. 本報では, この抗菌紙の有効利用を図るため に, 紙の作製条件を種々変化させ, ホ夕テ粒子の紙中で の分散状態が得られた抗菌紙の抗菌性に及ぼす影響につ いて, MRSAを対象に考察した.

\section{2. 実 験}

\subsection{MRSA の最小発育阻止濃度の測定}

まず最初に, 抗菌性を発現できると考えられる紙中の ホ夕テ粒子濃度を決定するために, ホ夕テ粒子水溶液の MRSA に対する最小発育阻止濃度 (MIC) を以下の方法で 測定した. すなわち, ホタテ粒子(東京ナノ・゙イオテクノ ロジー社製)を蒸留水に分散させ、7.8から $4000 \mu \mathrm{g} / \mathrm{ml}$ の 2 倍希釈ずつ段階希釈した水溶液を作製した。そこに $1 \times 10^{5}$ 個 $/ \mathrm{ml}$ に調製した MRSA(IID-1677)を各水溶液に接 種した. 数分後に, 各水溶液に接種した菌液 $1 \mathrm{ml}$ をシャー レに添加して寒天培地を加え, $37^{\circ} \mathrm{C} に て 24$ 時間, 静置培 養後, 菌の発育をコロニー形成によって判定し, MICを 決定した. 


\section{2 ホタテ粒子複合ピスを用いた抗菌紙の作製}

抗菌紙は既報 [5]と同様の方法によって作製した。す すな わち，JIS-P-8222(パルプ一試験用手すき紙の調製方法)を 参考に, 紙の原料としてサトゥキビバガスから作られた パルプ(Environmental Pulp and Paper Company Limited(夕 イ)製，以下パルプと称す)を叨解し，カナダ標準滤水度 を $97 \mathrm{ml}$ にしたパルプ(坪量 $54 \mathrm{~g} / \mathrm{m}^{2}$ ) に，サトウキビの芯部 であるピスにホタテ粒子を付着させ粉砕したもの（以下， $\mathrm{SP}$ と称す)を, 種々の比率で変化させて混抄した。 また 抄紙時の条件としては, SP を脱気せず混抄 (case1), 水中 で脱気した SPを混抄(case1-D)，ホ夕テ粒子，ピスおよ びパルプを単純に混抄(case2)，ピスを用いずホタテ粒子 のみを混抄(case3)ならびにcase2, case3 においてそれぞ れ脱気処理した case2-D および case3-D の 6 通りに変化さ せた．また，抗菌性を明確にするために，ホ夕テ粒子濃 度が約 10 倍ずつ異なるように, 各 case において 3 水準の 濃度の異なる抗菌紙を作製した。これらの抗菌紙は各オー ダーごとに, 最も低い濃度から GroupA, B 抢よび C と呼 ぶことにする.

\section{3 電子顕微鏡観察}

それぞれの case で作製した紙の SP の分布状態を調べる ために, 走査型電子顕微鏡 (SEM) (VE-9800: 株式会社 KEYENCE)を用いて紙の表裏面と断面を観察した．表面 とは抄紙時に扔ける原料混合物が積層上面であり, 裏面 とは抄紙機のタンク下部に設置したワイヤーメッシュに 接している側を意味する。断面観察には，垂直スライサー (HS-1 型 : ジャスコエンジニアリング株式会社)を用いて 切断した試料を用いた。

\subsection{EPMA カラーマッピング}

ホ夕テ粒子の表面の分布状態，とくに抗菌性試験結果 に影響を及ぼすと考えられる露出しているホタテ粒子の 分布状態をより詳細に調査するために電子線マイクロア ナライザ(EPMA) (JXA-8200 : 日本電子株式会社製)を用い て, カルシウムを対象元素としてカラーマッピングを行っ た. 表裏面については SEM 同様，表面が抄紙時における 原料混合物の積層上面であり, 裏面とは抄紙機のタンク 下部に設置したワイヤーメッシュに接している側を意味 する.

\section{5 孔径測定}

作製した紙の孔径は，キャピラリーポロメータ（CFP1100-AXL-ESA : PMI 社製)によって測定した．本機での 測定時にはサンプルに表面張力既知の液体を浸潤させる 必要があり，その液体として GALWICK (表面張力 1.6× $10^{-4} \mathrm{~N} / \mathrm{cm}^{2}$ : PMI 社製)を用いた。

\subsection{MRSA に対する抗菌性試験}

作製した各機能紙の MRSA に対する抗菌作用を調べる ために, JIS L1902(瀻維製品の抗菌性試験方法及び抗菌効 果)を参考に抗菌性試験を行った。すなわち，各サンプル $0.4 \mathrm{~g}$ をバイアル瓶に入れ, オートクレーブで高圧蒸気殺 菌後, クリーンベンチ内で 60 分間乾燥したものを試験片
とし、そこに, $3 \times 10^{5}$ 個 $/ \mathrm{ml}$ の菌液を $0.2 \mathrm{ml}$ 接種し, $37^{\circ} \mathrm{C}$ にて所定時間 $(30,60,1440$ 分) 培養した. 菌数は, 菌液接 種直後掞よび培養後に生理食塩水 $20 \mathrm{~mL}$ を加え, 手振り (振幅 $30 \mathrm{~cm}, 30$ 回振とう) で各検体から菌を洗い出し, トリプチケースソイ寒天培地を用い, $37^{\circ} \mathrm{C} に て 48$ 時間, 混釈平板培養を行い測定した。 また, 殺菌活性值は常法 に従って算出した.

\section{7 抗菌性試験結果に対する有意差検定}

抗菌性試験結果に対する有意差検定は， 3 水準以上含む データの場合に扔いて，まず一元配置分散分析による有 意差検定を行った. 有意差 $(P<0.01)$ が認められた場合, Holm 法により水準間の多重比較検定を行い, $P<0.01$ の 場合に有意差があると判断した. 2 水準での比較は $t$ 検定 を行い, $P<0.01$ の場合に有意差があると判断した。

\section{3. 結果と考察}

\subsection{MRSA の最小発育阻止濃度}

各焼成ホ夕テ粒子水溶液の状態は, $4000 \mu \mathrm{g} / \mathrm{ml}$ では白濁

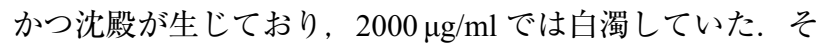
れ以下の濃度では透明であった。このことは，ホ夕テ粒 子の主成分が水酸化カルシウムであり, 水酸化カルシウ 么の水への溶解度が $0.17 \mathrm{~g} / 100 \mathrm{ml}\left(25^{\circ} \mathrm{C}\right)$ であることから, その溶解度を単位換算すると $1700 \mu \mathrm{g} / \mathrm{ml}$ となり, 観察さ れた状態と一致した。これらの 2 倍ずつ段階希釈した各 水溶液によって MRSA に対するホ夕テ粒子の MIC を測定 した結果, Table1 に示す通り, その濃度は $500 \mu \mathrm{g} / \mathrm{ml}$ であっ た.

Table 1 Minimum inhibitory concentration of burned scallop particles aqueous solution for MRSA.

\begin{tabular}{cc} 
Concentration $(\mu \mathrm{g} / \mathrm{ml})$ & MRSA \\
\hline 4000 & - \\
2000 & - \\
1000 & - \\
500 & - \\
250 & + \\
125 & + \\
62.5 & + \\
31.3 & + \\
15.6 & + \\
7.8 & + \\
\hline
\end{tabular}

\section{2 抗菌紙中のホタテ粒子濃度}

MIC の結果 $(500 \mu \mathrm{g} / \mathrm{ml})$ に基づき，抗菌性試験において, 接種した菌液が $0.2 \mathrm{ml}$ であり, 試験片の重量が $0.4 \mathrm{~g}$ であ ることから、抗菌紙のホタテ粒子濃度が $0.25 \mathrm{mg} / \mathrm{g}$ 以上に おいて、MRSAに対する抗菌性を発現すると期待できる. そこで, 抗菌紙のホ夕テ粒子濃度が $0.25 \mathrm{mg} / \mathrm{g}$ 以上になる ように, さらに抗菌性を確実に発現させるために, ホ夕 テ粒子濃度のオーダーが 1 桁ずつ変わるように各抗菌紙 を作製した．作製した抗菌紙のホタテ粒子濃度を Table2 に示す. 各 caseによって多少の差異はあるものの最低ホ 
タテ粒子濃度が $0.23 \mathrm{mg} / \mathrm{g}$ 以上であることが確認できた. またホタテ粒子の分散状態を変えた抗菌紙における分散 状態の差異が抗菌性に及ぼす影響を見出すために, 各 case の濃度のオーダーが統一されるように抗菌紙を作製し,

各 Group において同等のオーダーとなっていることが確 認できた.

Table 2 Concentrations (mg/g) of burned scallop particles in antibacterial papers.

\begin{tabular}{lrrrrrr} 
& case1 & case1-D & case2 & case2-D & case3 & case3-D \\
\hline Group A & 0.32 & 0.23 & 0.26 & 0.31 & 0.25 & 0.26 \\
Group B & 3.34 & 1.91 & 2.01 & 2.86 & 2.08 & 2.12 \\
Group C & 24.29 & 15.10 & 13.14 & 23.38 & 12.16 & 12.61 \\
\hline
\end{tabular}

\section{3 抗菌紙中のホタテ粒子分散状態}

case1 では, 抄紙工程において水中に懸濁している SP が抄紙夕ンク内の水面にその多くが浮遊するため, 夕ン ク下方から水抜きを行い脱水し, 紙層形成をしていく際 に, 最後に沈降して積層することにより SP を紙表面に集 中させることができるのに対し, case1-Dでは SPを水中 で脱気することによって, タンク内の水面に浮遊するこ となく, 紙中のパルプと SP を比較的均一分散して混抄す ることができることが分かっている[5]. 本報において, それぞれの条件で作製した紙のSP の分散状態について, SEM 観察した結果を Fig. 1 に示す. 既報 [5]と同様に，ピ スを用いて脱気していない case1 および case2 ではピスは

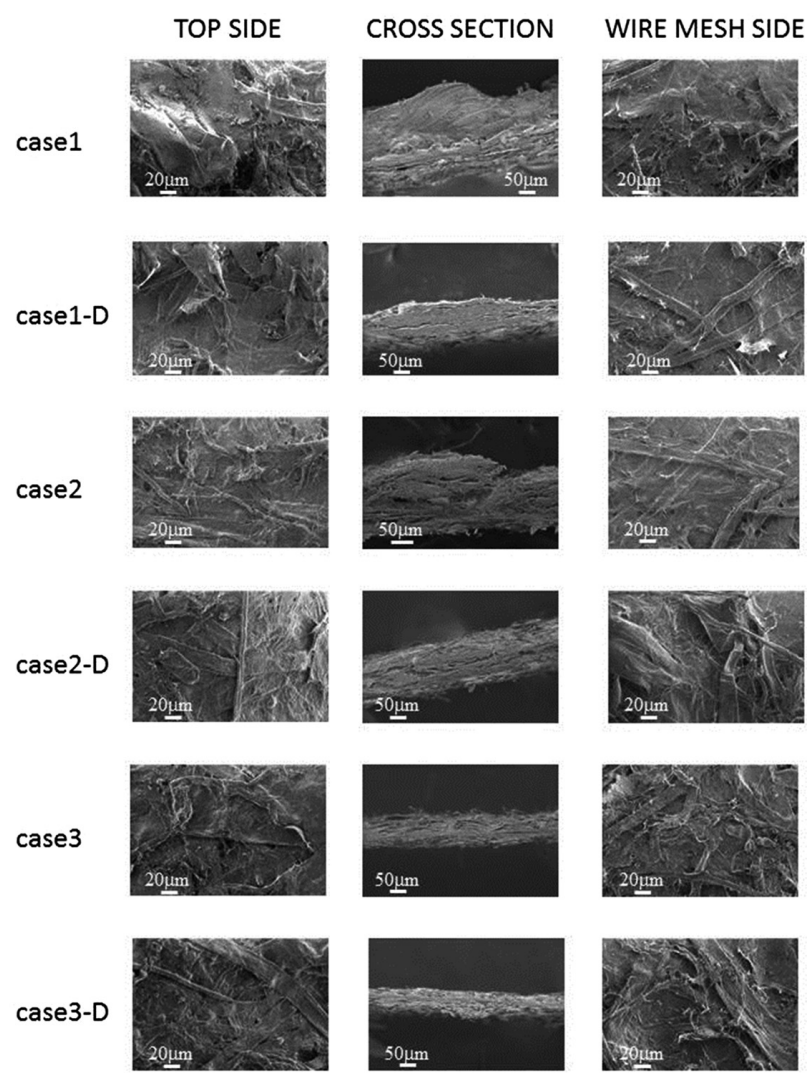

Fig. 1 SEM photomicrographs of distribution of scallop particle in paper for each case (Bagasse pith or composite pith : enclosed in circle with arrow, Scallop particles : dashed arrow).
表面上に観察され，脱気した case1-D および case2-D では ピスは紙内部に存在していることが確認された.

EPMA によるカラーマッピングの結果を Fig. 2 に示す. 画像の赤色箇所が表面上に存在しているホ夕テ粒子であ り, それ以外はパルプに覆われ, 露出していないと考え られる. case1 において表面に露出しているホ夕テ粒子が その他の case よりも多いことが EPMAによって明らかと なった.

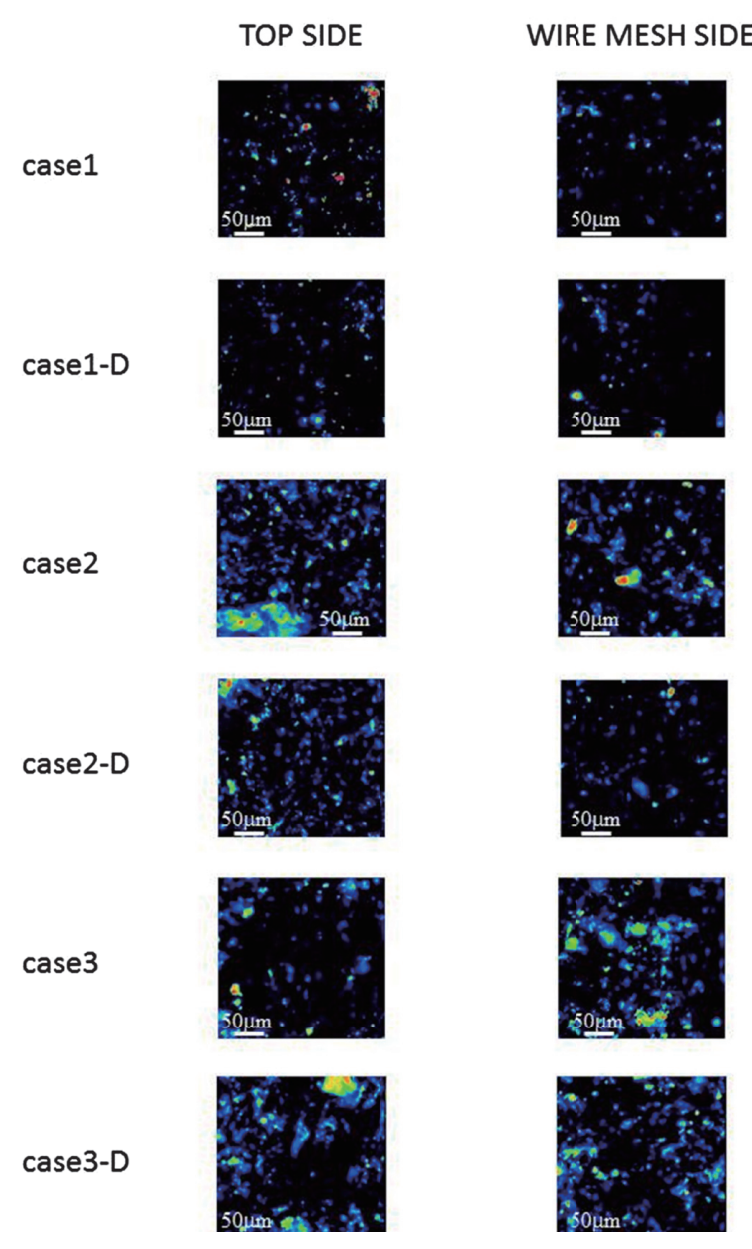

Fig. 2 EPMA mapping images for $\mathrm{Ca}$ in each paper.

\section{4 抄紙条件がMRSA に対する抗菌性に及ぼす影響}

Fig. 3 は, 各 Group, 各 case に対する菌接種 30 分培養 後の殺菌活性值を示す。まず Group 内での比較を行った。 各 case での Group A 内および Group B 内における有意差 は確認されず, GroupCにおいては, Table3(1)に示す通 り, case1 と case2 で全ての case に対して有意差があった。 したがって, 菌接種 30 分培養後では, 濃度の低い Group A および Group B では作製条件の違いによって抗菌性に有 意な差はなかったが, 濃度の最も高いGroup Cにおいて case1 が最も高い抗菌性を示したと言える. 次に, Group 間で比較すると, Group A と Group B において Group B は Group A よりもホタテ粒子濃度が約 10 倍高く, 殺菌活性 值は上昇したものの, 有意差が確認されたのは case1, case 2-D および case3-Dであり, その変化は小さかった. 一方 で GroupCでは, case1, case2 および case3-Dにおいて 


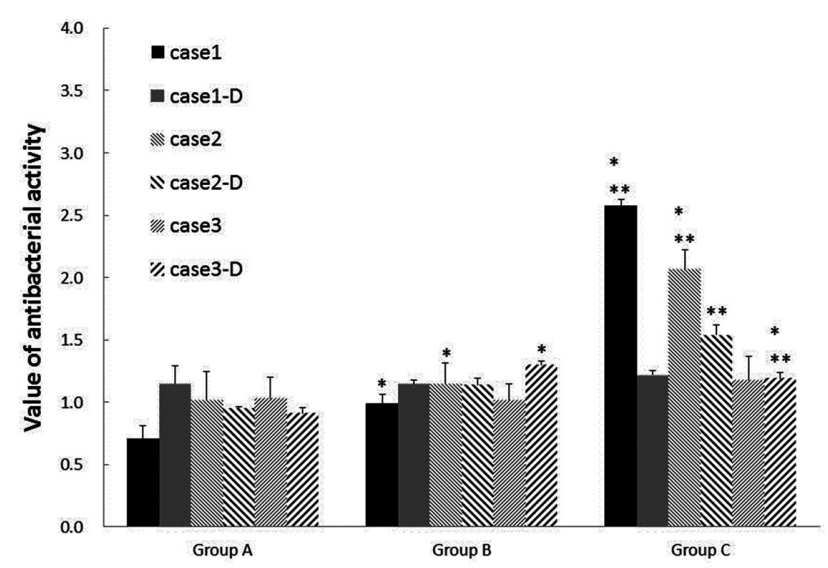

Fig. 3 Values of antibacterial activity in each group after 30minutes of cultivation. One asterisk and two asterisks indicate a significant difference for Group A and for Group B in each case, respectively $(P<0.01)$.

Table 3 Correspondence table of significant difference of antibacterial activity within every group of cultivation time for each case in Group C. "Y" indicate the combination has significant difference, and " $\mathrm{N}$ " indicate the combination has no significant difference.

\begin{tabular}{l|ccccc} 
(1) $30 \mathrm{~min}$ & case1 & case1-D & case2 & case2-D & case3 \\
\hline case1-D & $\mathrm{Y}$ & - & - & - & - \\
case2 & $\mathrm{Y}$ & $\mathrm{Y}$ & - & - & - \\
case2-D & $\mathrm{Y}$ & $\mathrm{N}$ & $\mathrm{Y}$ & - & - \\
case3 & $\mathrm{Y}$ & $\mathrm{N}$ & $\mathrm{Y}$ & $\mathrm{N}$ & - \\
case3-D & $\mathrm{Y}$ & $\mathrm{N}$ & $\mathrm{Y}$ & $\mathrm{N}$ & $\mathrm{N}$
\end{tabular}

\begin{tabular}{l|ccccc} 
(2) $60 \min$ & case1 & case1-D & case2 & case2-D & case3 \\
\hline case1-D & Y & - & - & - & - \\
case2 & $\mathrm{Y}$ & $\mathrm{Y}$ & - & - & - \\
case2-D & $\mathrm{Y}$ & $\mathrm{N}$ & $\mathrm{Y}$ & - & - \\
case3 & $\mathrm{Y}$ & $\mathrm{N}$ & $\mathrm{Y}$ & $\mathrm{N}$ & - \\
case3-D & $\mathrm{Y}$ & $\mathrm{N}$ & $\mathrm{Y}$ & $\mathrm{N}$ & $\mathrm{N}$
\end{tabular}

\begin{tabular}{l|ccccc} 
(3) $1440 \mathrm{~min}$ & case1 & case1-D & case2 & case2-D & case3 \\
\hline case1-D & $\mathrm{Y}$ & - & - & - & - \\
case2 & $\mathrm{Y}$ & $\mathrm{N}$ & - & - & - \\
case2-D & $\mathrm{N}$ & $\mathrm{Y}$ & $\mathrm{Y}$ & - & - \\
case3 & $\mathrm{Y}$ & $\mathrm{N}$ & $\mathrm{N}$ & $\mathrm{Y}$ & - \\
case3-D & $\mathrm{N}$ & $\mathrm{N}$ & $\mathrm{N}$ & $\mathrm{N}$ & $\mathrm{N}$
\end{tabular}

Group A および Group B に対し有意差があり，とくに case1 および case2 では高い殺菌活性值を示したが, case1-D と case3 ではどの Group とも有意差はなかった.

ここで、作製した紙の孔径を測定した結果，最大径が $0.2 \mu \mathrm{m}$ であり, MRSA の菌体直径が $0.7 \mu \mathrm{m}$ 程度 [6]とされ ていることから, MRSA が紙内部に入りやすい状態では ないため, MRSAが紙表面により多く存在していると考 えられる.したがって, SPを用いている case1 と case1-D において, case1 が高い殺菌活性值を示したのは, SP が紙 表面に比較的多く存在しているためにMRSA と SP が接 触する可能性が高く, その結果として高い殺菌活性值を 示したと推察される. 次に case 2 が高い殺菌活性值を示し

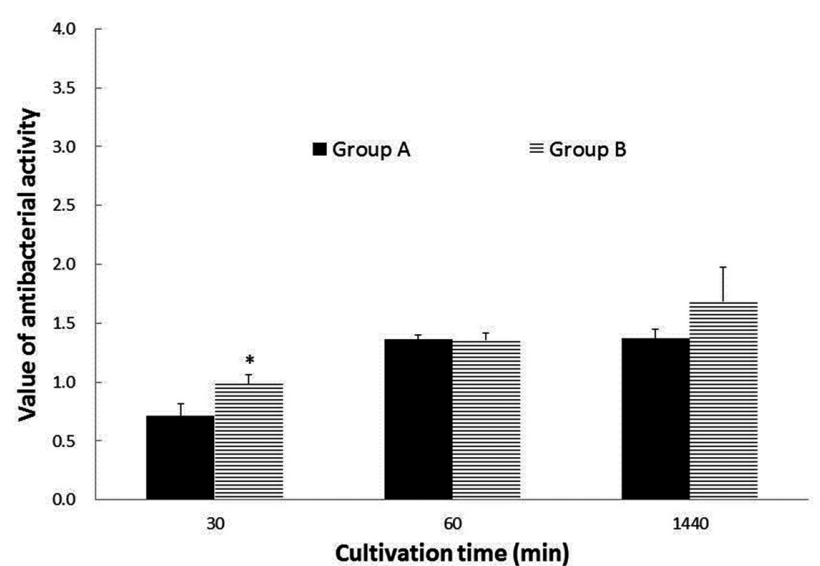

Fig. 4 Values of antibacterial activity of case1 in Group A and Group B after 30, 60 and 1440 minutes of cultivation, respectively. One asterisk indicates a significant difference for Group A $(P<0.01)$.

た理由としては, ホタテ粒子に起因する抗菌性のみなら ず，バガスピスやバガスパルプも抗菌性を有しているこ とが挙げられる。サトウキビには抗菌性物質として, エ ピカテキンの存在が知られており [7], またそのエピカテ キンが MRSA に対して抗菌性があることもわかっている [8]. ホ夕テ粒子を混抄した抗菌紙と同様に, バガスピス やバガスパルプに対して菌接種 30 分培養後の殺菌活性值 を測定した結果それぞれ 0.94 および 0.56 であり，菌数の 低下が確認された．また case2 は case1 と同様に脱気処理 をしていないことにより表面付近に比較的多くのピスが 存在しているため, case2 においても高い殺菌活性值を示 したと推察した.

Fig. 4 に, Group A および Group B における case1 の菌接 種後 30, 60, 1440 分培養後の殺菌活性值を示す. Group A および Group B では, 菌接種後 30 分培養では殺菌活性值 に有意差があり,さらに菌接種後 30 分培養と 60 分培養 ではともに殺菌活性值は上がった。しかしながら，菌接 種後 60 分培養において Group A と Group B の殺菌活性值 に差はなくなり, さらに 1440 分培養では, 60 分培養と比 較して殺菌活性值が上昇することはなかった。 したがっ て, 本報では MRSA のホタテ粒子溶液の MICより抗菌紙 中に含まれるホ夕テ粒子量を設定したが, 前述のように MRSA が紙の表面上に存在していると考えられるため, 紙表面付近のホ夕テ粒子が抗菌活性を示し, 抗菌紙中に 含まれる全てのホ夕テ粒子が抗菌性に寄与するわけでは ないと考えられ, Group A ならびにGroup B のホタテ粒子 量では十分な抗菌性が発現されないと判断された。 そこ で, 次に各 case での菌接種後 30, 60, 1440 分培養後の殺 菌活性值については, 最も濃度の高いGroup Cにおける 結果について吟味する.

Fig. 5 に Group C における各 case の菌接種後 30, 60, 1440 分培養後の殺菌活性值, Table3 に各 case における各 培養時間グループ内の有意差検定の結果を示す. Group C 


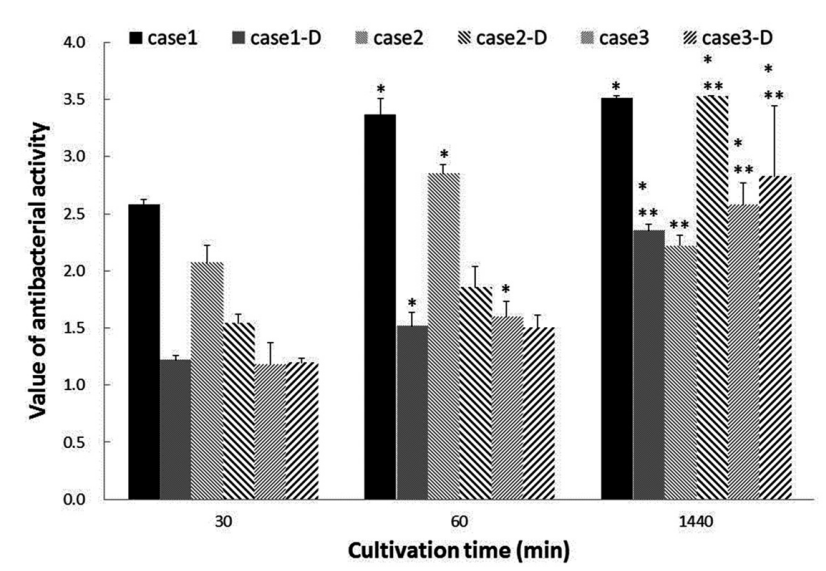

Fig. 5 Values of antibacterial activity of Group $C$ in each case after 30, 60 and 1440minutes of cultivation, respectively. One asterisk and two asterisks indicate a significant difference for $30 \mathrm{~min}$ and for $60 \mathrm{~min}$ of cultivation in each case, respectively $(P<0.01)$.

では，培養時間が長くなると， case2 を除き殺菌活性值は 上昇した，JIS においては，殺菌活性值が 0 以上において その試料は抗菌性を有すると判断されるが, とくに case 1 では, 30 分および 60 分培養において抗菌活性值は 2.5 以 上であり，他の全ての case と比較して有意差のある高い 殺菌活性值を示し，1440 分培養においても高い殺菌活性 值を維持した。一方で, 菌接種後 30 分培養において 2.0 以上の高い殺菌活性值を示した case2 は, 60 分培養後に おいては 30 分培養後よりも殺菌活性值が上がったが, 1440 分培養後には低下した。また case3-Dでは, 1440 分 培養後の殺菌活性值は, 培養時間の違いによる比較では 有意差があったが, 1440 分培養後内の他の case と比較し た場合, 有意差が確認されなかった.これらの原因につ いては, サトウキビ由来のバガスが天然物であるため, 前述の通り抗菌性を発現するとされるエピカテキンの存 在量にバラツキがある[7]ためと考えられるが, その詳細 は本報では明らかにすることはできなかった。

これらの結果より, 天然物が元来有している抗菌性の 発現の程度をコントロールすることは困難であることが 示唆されたのに対して, SP 用いて脱気処理をせず紙表 面のホ夕テ粒子濃度を高めた case1 の条件で作製した抗菌 紙は安定的に高い殺菌活性值を示し, MRSA に対して有 効的な抗菌紙であると言える.

\section{4. 結 言}

本報ではピスの多孔質部にホタテ粒子を付着させた SP を用いて抗菌紙を作製し, MRSAに対する抗菌性を評価 した．SPを脱気せず，抄紙タンク内の水面に懸濁してい る SP の多くを浮遊させた状態で抄紙することによって, 脱水時の紙層形成の最後に SP を沈降, 積層させ, 紙表面 の SP 濃度を高めた抗菌紙は, ホ夕テ粒子付着ピスを用い ないで作製した抗菌紙と比較して，MRSAに対する高い 抗菌性が, とくに菌接種後 30 分培養の時点で確認された。 すなわち, ホ夕テ粒子水溶液単体と同様に, ホ夕テ粒子 をピスを用いて紙に抄き込むことによっても即効性に優 れた抗菌紙が得られることが明らかになった。

また，バガスパルプやピス自体にも抗菌性があったが, これらは天然物であることから, 含まれている抗菌性物 質にバラツキがあるため, 安定的な抗菌性を紙に付与す ることは容易でないことが示唆された，一方で, SP と混 抄し, 抗菌性物質であるホ夕テ粒子の分散を表面に集中 させることによって, 高い抗菌性を安定して発現できる と考えられる.

\section{文 献}

1. Fuji Keizai Co., Ltd, Osaka Marketing Division, "Koukinkakouseihin no naigaisijyounikansuru chosahoukokusyo”, Fuji Keizai Co., Ltd, p.1 (2004).

2. Y. Tanabe, Jpn. J. Clin. Dermatol., 66, 88 (2012).

3. T. Sano, J. Med. Soc. Toho Univ., 59, 320 (2012).

4. T. Yoshida, N. Koyama, S. Okuda, K. Sasaya, C. Fukuhara and T. Kohriyama, Bull. Res. Inst. Interdiscip. Sci., Hachinohe Inst. Technol., 1, 117 (2002).

5. R. Oda, T. Kimura and H. Inagaki, Sen'i Gakkaishi, 70, 3 (2014).

6. M. Yamamura, M. Noda, U. Ito, I. Takase, S. Asai, M. Nakanishi, J Ohsawa, M. Shinoda and Isamu Namikawa, Jpn. J. Oral Biol., 35, 21 (1993).

7. D. Kannar, B. J. Kitchen, United States Patent, US 20100291006 A1.

8. M. Toda, S. Okubo, Y. Hara and T. Shimamura, Jpn. J. Bacteriol., 46, 839 (2009). 